\title{
CORRECTION
}

\section{The complex structure of ATXN2 genetic variation}

Neurol Genet 2019;5:e311. doi:10.1212/NXG.0000000000000311

In the editorial, "The complex structure of ATXN2 genetic variation," by Pulst ${ }^{1}$, first published online December 6, 2018, the reference for Tojima et al.'s article should read: 1. Tojima M, Murakami G, Hikawa R, et al. Homozygous 31 trinucleotide repeats in the SCA2 allele are pathogenic for cerebellar ataxia. Neurol Genet 2018;4:e283. DOI: 10.1212/NXG.0000000000000283. The publisher regrets the error.

\section{Reference}

1 Pulst SM. The complex structure of ATXN2 genetic variation. Neurol Genet 2018;4:e299. DOI: 10.1212/NXG.0000000000000299 


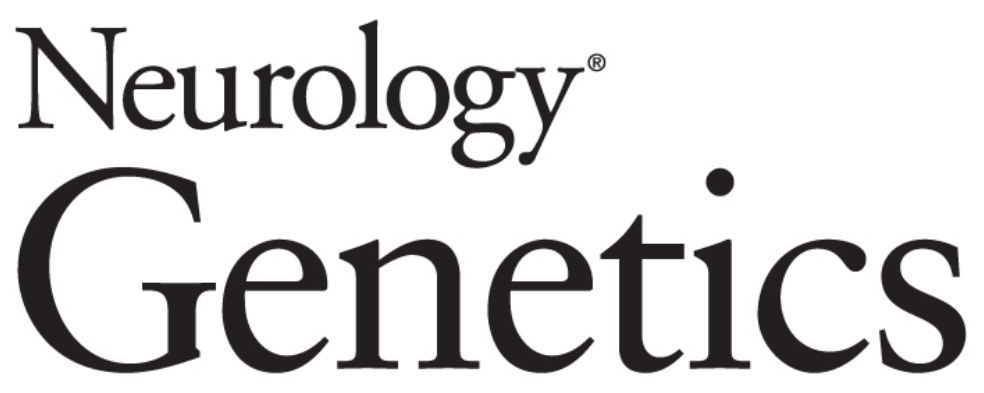

The complex structure of ATXN2 genetic variation

Neurol Genet 2019;5;

DOI 10.1212/NXG.0000000000000311

This information is current as of February 4, 2019

Updated Information \& Services

References

Permissions \& Licensing

Reprints including high resolution figures, can be found at: http://ng.neurology.org/content/5/1/e311.full.html

This article cites 1 articles, 1 of which you can access for free at: http://ng.neurology.org/content/5/1/e311.full.html\#\#ref-list-1

Information about reproducing this article in parts (figures,tables) or in its entirety can be found online at:

http://ng.neurology.org/misc/about.xhtml\#permissions

Information about ordering reprints can be found online: http://ng.neurology.org/misc/addir.xhtml\#reprintsus

Neurol Genet is an official journal of the American Academy of Neurology. Published since April 2015, it is an open-access, online-only, continuous publication journal. Copyright ( 2019 American Academy of Neurology. All rights reserved. Online ISSN: 2376-7839.

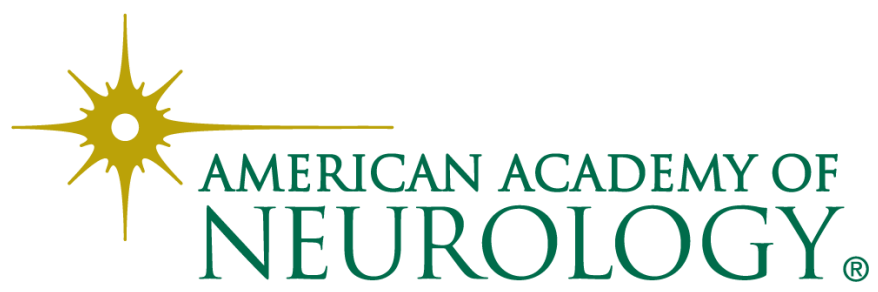

